\title{
Conditioning with TLI/ATG in Hematopoietic Stem Cell Transplantation from Haploidentical Donors with Post-transplant Cyclophosphamide in Children in a Single Center During 2015-2017
}

\author{
Catalina María Acevedo-HENAO ${ }^{1,2}$, Nelson Romero-ROSAS ${ }^{2}$, Estefania BELTRAN ${ }^{3}$, \\ Eliana MANZI ${ }^{2,3}$, Alexis Antonio Franco MORENO ${ }^{2,4}$, Mayra ESTACIO ${ }^{3}$, \\ Guillermo Potdevin STEIN ${ }^{1,2}$, Diego Medina VALENCIA ${ }^{2,4}$ \\ ${ }^{1}$ Fundación Valle del Lili, Department of Radiotherapy, Cali \\ ${ }^{2}$ Universidad Icesi, Faculty of Health Science, Department of Medicine, Cali \\ ${ }^{3}$ Fundación Valle del Lili, Sub Directorate of Clinical Research, Center for Clinical Research, Cali \\ ${ }^{4}$ Fundación Valle del Lili, Pediatric Stem Cell Transplant Service, Cali, COLOMBIA
}

\begin{abstract}
Hematopoietic stem cell transplantation is a treatment alternative for some benign blood disorders. The use of nonmyeloablative conditioning with total lymphoid irradiation and anti-thymocyte globulin has decreased the incidence of acute graft-versus-host disease and can reduce the complications of total body irradiation and generate sustained chimerism. Posttransplant cyclophosphamide has also shown benefits. This is a retrospective, case-series study of pediatric patients with benign pathologies who were treated at Fundación Valle del Lili. A descriptive analysis was performed with measures of central tendency. Survival outcomes were calculated using the Kaplan-Meier estimator. Twelve patients (50\% female) with benign blood disorders were included, with an average age of $8.2 \pm 5.7$ years. The type of donor was haploidentical in all cases; in half, the cellular source was bone marrow. Fifty percent had a diagnosis of immunodeficiencies. The average follow-up time was 28.9 months. The total lymphoid irradiation dose corresponded to a median of 750 centigrays (IQR: 400-750). Neutrophil grafting was achieved in 12/12 patients, and platelet grafting was achieved in $11 / 12$ patients. The presentation of acute graft-versus-host disease was $58 \%$. The transplant related mortality was $17 \%$, and the 1 -year overall survival was $83 \%$. Conditioning with total lymphoid irradiation and anti-thymocyte globulin and the use of posttransplant cyclophosphamide is a viable alternative; however, it did not decrease the cases of acute graft-versus-host disease.
\end{abstract}

Keywords: Stem cell transplant, Thymoglobulin, Lymphatic irradiation, Child, Adolescent

\section{INTRODUCTION}

Hematopoietic stem cell transplantation (HSCT) is a curative treatment option for different hematological pathologies in pediatrics. ${ }^{1-3}$ In 1968 , a successful case of a pediatric patient treated for severe combined immunodeficiency (SCID) was reported. ${ }^{4,5}$; since 1976, different TLI-based conditioning strategies have been used in both adults and children with good results. ${ }^{6}$ Among the main benign pathologies in which this conditioning regimen has been applied are primary immunodeficiencies, hemoglobinopathies, bone marrow failure syn- dromes (BMFSs), and others. ${ }^{5,7,8}$

In terms of the types of donors, the ideal donor is an identical family member; however, this situation is only found in approximately $30 \%$ of cases. ${ }^{9}$ Therefore, alternative donors are usually required, and their selection depends on the availability and expertise of the transplant center.

Nonmyeloablative conditioning with TLI and antithymocyte globulin (ATG) has been shown to decrease the incidence of acute graft-versus-host disease (GVHD) and the complications of irradiation. 
It also leads to sustained chimerism and protects against donor-recipient alloreactivity, with high rates of survival in murine models and humans through the depletion of $\mathrm{T}$ cell populations and the survival of natural killer $\mathrm{T}$ cells, which polarize donor $\mathrm{T}$ cells towards the type 2 helper phenotype (anti-inflammatory subtype). Additionally, donor regulatory $\mathrm{T}$ cells expand and secrete interleukin-10 (IL-10). ${ }^{10,11}$ In addition, the use of TLI has been associated with minimal adverse effects, likely due to the lower amount of irradiated body area, especially when using intensity modulation and the volumetric modulated arc therapy (VMAT) technique. ${ }^{12}$ This modality has also been used in HSCT of haploidentical donors with graft manipulation. ${ }^{13}$

Regarding the use of post-HSCT cyclophosphamide (Cy), there has been evidence of benefits in the modulation of GVHD in human leukocyte antigen-identical (HLA-identical) and haploidentical donors in different types of pathologies in both adults and children. ${ }^{14,15}$ The use of post-HSCT Cy in a pediatric population with benign disorders undergoing haploidentical HSCT leads to high overall survival (OS), low rates of GVHD and complications and disease resolution. ${ }^{14,16}$

Knowing that post-HSCT Cy has been used in multiple conditioning strategies and different donor types and given the benefit of TLI in GVHD, it was hypothesized that this combination could benefit patients with benign pathologies.

The objective of this study was to describe the treatment modality and outcomes of pediatric patients treated with TLI/ATG conditioning and postHSCT Cy for hematological benign disorders between 2015 and 2017 at a tertiary care center.

\section{MATERIAL AND METHODS}

An observational, retrospective, case-series study of pediatric patients with benign pathologies treated at Fundación Valle del Lili between 2015 and 2017 was conducted. The information was collected through the institutional database of transplants, selecting the transplant patients with benign hematological pathologies recorded in their medical history. Subsequently, the following selection criteria were applied: patients younger than 18 years of age with a diagnosis of benign hematological pathology based on clinical symptoms and paraclinical studies who had received pretransplant conditioning based on TLI/ATG and post-HSCT Cy, had a haploidentical donor, and had undergone transplant at the institution. Patients were excluded whenever data were incomplete. One patient was excluded for malignant pathology and another for having an identical-matched relative. This study was approved by the institutional ethics committee.

\section{Transplantation}

Conditioning regimen: Reduced-intensity protocols based on fludarabine (Flu) $30 \mathrm{mg} / \mathrm{m}^{2}$ on days -5 to -2, Cy $15 \mathrm{mg} / \mathrm{kg}$ days -6 to -5 , rabbit ATG $5 \mathrm{mg} / \mathrm{kg}$ cumulative dose and, in one case, horse ATG $30 \mathrm{mg} / \mathrm{kg}$ days -9 to -7 , and TLI on day -8 or -1 . This variation occurred because, in some cases, the intention was an early application to avoid the inconveniences with edema after ATG, which could affect the initial simulation of the procedure. Furthermore, the dose administered in centigrays (cGy) was according to age. In two cases, additional medicines were added: Busulfan (BU) according to weight on days -4 to -2 and, in one case, Rituximab $375 \mathrm{mg} / \mathrm{m}^{2} /$ dose since day $-9 .{ }^{17}$

Prophylaxis for graft-versus-host-disease: A regimen based on posttransplant $\mathrm{Cy}$ on days +3 and +4 was used at a dose of $50 \mathrm{mg} / \mathrm{kg} / \mathrm{day}^{18}$, with cyclosporine (CsA) every 12 hours beginning on day +4 while monitoring CsA levels to maintain a level of approximately $200 \mathrm{ng} / \mathrm{Ml}$. The CsA start day was a local decision in order to obtain better and early levels and decrease GVHD presentation. In some cases, sirolimus ( $\mathrm{Srl}$ ) was added for 4 days according to the pharmaceutical recommendation; mycophenolate mofetil (MMF) was added at a dose of $15 \mathrm{mg} / \mathrm{kg}$ every 8 hours orally from day +4 until +30 ; or methotrexate $(\mathrm{Mtx})^{19}$ was added at a dose between 5 and $7.5 \mathrm{mg} / \mathrm{m}^{2}$ on days $+5,+7,+10$ and +15 with calcium folinate as the rescue agent.

TLI/ATG regimen: The procedure performed at the institution began with intravenous administration of ATG pre-HSCT. Next, a total dose of TLI between 400 and 750 cGy was administered in a single dose on day -1 and, in two cases, was performed on day -8 of HSCT using the Artiste Sie- 
International Journal of Hematology and Oncology

\begin{tabular}{|c|c|c|c|c|c|c|c|c|c|}
\hline ID & Age & Gender & DX & $\begin{array}{l}\text { Conditioning } \\
\text { Regimen }\end{array}$ & AGVHD & CGVHD & Infections & $\begin{array}{l}\text { Follow- } \\
\text { up* }\end{array}$ & $\begin{array}{l}\text { Vital } \\
\text { Status }\end{array}$ \\
\hline 1 & 6 & $\mathrm{~F}$ & SCA & $\begin{array}{c}\text { Cy, Flu, ATG, TLI } \\
\text { (750 cGy) }\end{array}$ & No & No & No & 25 & Alive \\
\hline 2 & 10 & $\mathrm{~F}$ & SCA & Cy, Flu, ATG, TLI & No & No & $\begin{array}{l}\text { Bacterial, } \\
\text { Fungal, Viral }\end{array}$ & 55 & Alive \\
\hline 3 & 12 & $\mathrm{~F}$ & SCA & $\begin{array}{l}\text { Cy, Flu, ATG, TLI } \\
\text { (750 cGy) }\end{array}$ & Gll Hepatic & No & Bacterial & 32 & Alive \\
\hline 4 & 14 & $\mathrm{~F}$ & SCA & $\begin{array}{l}\text { Cy, Flu, ATG, TLI } \\
\text { (750 cGy) }\end{array}$ & $\begin{array}{l}\text { Gll-Gastro- } \\
\text { intestinal }\end{array}$ & No & No & 49 & Alive \\
\hline 5 & 0.5 & M & CGD & $\begin{array}{l}\text { Cy, Flu, ATG, TLI } \\
\text { (400 cGy) }\end{array}$ & No & No & $\begin{array}{l}\text { Bacterial, } \\
\text { Fungal }\end{array}$ & 1.5 & Dead \\
\hline 6 & 1 & M & CGD & $\begin{array}{l}\text { Cy, Bu, Flu, ATG, TLI } \\
\text { (400 cGy) }\end{array}$ & No & Severe & No & 43 & Alive \\
\hline 7 & 1 & $\mathrm{~F}$ & CGD & $\begin{array}{l}\text { Cy, Bu, Flu, ATG, TLI } \\
\text { (400 cGy) }\end{array}$ & $\begin{array}{l}\text { Gl-gastro- } \\
\text { intestinal }\end{array}$ & Moderate & No & 39 & Alive \\
\hline 8 & 3 & M & ID1 & $\begin{array}{l}\text { Cy, Bu, Flu, ATG, TLI } \\
\text { (750 cGy) }\end{array}$ & No & Moderate & Bacterial & 44 & Alive \\
\hline 9 & 3 & M & ID2 & $\begin{array}{l}\text { Cy, Bu, Flu, ATG, TLI } \\
\text { (750 cGy) }\end{array}$ & $\begin{array}{l}\text { Gll-skin, } \\
\text { Glll-gastro- } \\
\text { intestinal }\end{array}$ & Moderate & $\begin{array}{l}\text { Bacterial, } \\
\text { KPC, Viral }\end{array}$ & 18 & Alive \\
\hline 10 & 4 & M & ID3 & $\begin{array}{l}\text { Cy, Bu, Flu, ATG, TLI } \\
\text { (450 cGy) }\end{array}$ & $\begin{array}{l}\text { Gll-skin, } \\
\text { Gl-hepatic }\end{array}$ & No & Fungal. & 34 & Alive \\
\hline 11 & 9 & $M$ & FA & $\begin{array}{l}\text { AraC, Flu, ATG, TLI } \\
\quad(400 \text { cGy) }\end{array}$ & Gll-skin, & $\begin{array}{l}\text { Mild } \\
\text { Gl-gastro- } \\
\text { intestinal }\end{array}$ & Viral & 23 & Alive \\
\hline 12 & 13 & $F$ & FA & $\begin{array}{l}\text { AraC, Flu, ATG, TLI } \\
\text { (400 cGy) }\end{array}$ & $\begin{array}{l}\text { GIll-gastro- } \\
\text { intestinal }\end{array}$ & No & $\begin{array}{l}\text { Bacterial, } \\
\text { Viral }\end{array}$ & 2.4 & Dead \\
\hline
\end{tabular}

mens linear accelerator with intensive modulated radiation therapy (IMRT) techniques with $6 \mathrm{MV}$ energy and a dose rate of $50 \mathrm{MU} / \mathrm{min}$. In all patients, the treatment session was performed under anesthesia. Patients were treated in the supine decubitus position on a vacuum mattress and with a thermoplastic mask. The treatment region included the lower mandibular, supra- and infraclavicular, axillary, mediastinal, hilar, paraaortic, pericaval, iliac, and inguinal lymph nodes; splenic hilum; spleen; and thymus. Risk organs were defined as the bone marrow, mandible, parotid, larynx, thyroid, humeral heads, lungs, heart, kidneys, intestinal loops, liver, bladder, rectum, femoral heads, mammary gland, ovaries, and testes.

\section{Antimicrobial Prophylaxis}

All patients received voriconazole, itraconazole or posaconazole as antifungal prophylaxis; trimethoprim/sulfamethoxazole as prophylaxis for Pneumocystis jirovecii; fluoroquinolones as antimicrobial prophylaxis; and acyclovir as antiviral prophylaxis. Doses and schedules were adjusted individually according to current international guidelines. $^{20}$

\section{Statistical Analysis}

A descriptive statistical analysis was performed for all variables considered. Categorical variables are summarized in proportions, and continuous variables are expressed as the means \pm standard de- 
viations (SDs) or medians with interquartile ranges (IQRs) according to the distribution of the variable. The primary outcomes of the study were treatment, complications, and OS in months calculated from the date of diagnosis or date of transplantation to the date of death or last follow-up at the institution. These outcomes were analyzed with the Kaplan-Meier method using the statistical software STATA® 12.1 .

\section{RESULTS}

\section{Description of the Case Series}

Twelve patients fulfilled the selection criteria from 2012-2017. An equal distribution was found between males and females, with an average age of $8.2 \pm 5.7$ years. The most frequent diagnostic group that required transplantation of hematopoietic cells was immunodeficiencies (50\%), followed by hemoglobinopathies (33\%). The average follow-up time was 28.9 months (Tables 1 and 2).

\begin{tabular}{|ll|}
\hline $\begin{array}{l}\text { Table 3. Characterization of non-myeloablative TLI / ATG } \\
\text { conditioning for HSCT }\end{array}$ \\
\hline Characteristics & Total (n= 12) \\
\hline Time of treatment with Tli & \\
30-60 Min, $n$ (\%) & $1(8)$ \\
60-90 Min, $n$ (\%) & $4(33)$ \\
> 90 Min, $n(\%)$ & $7(59)$ \\
Number of irradiated fields & \\
20-30, n (\%) & $3(25)$ \\
30-40, n (\%) & $5(42)$ \\
$>$ 40, n (\%) & $4(33)$ \\
Radiotherapy Dose In Cgy, Median (Ric) & $750(400-750)$ \\
Gvhd Prophylaxis & \\
Csa-Mtx-Cy, $n$ (\%) & $7(59)$ \\
Mmf-Cy-Srl, n (\%) & $1(8)$ \\
Mtx-Cy-Tac-Srl, n (\%) & $3(25)$ \\
Mtx-Mmf-Cy-Srl, n (\%) & $1(8)$ \\
Nucleated, Average \pm Sd & $153 \pm 58$ \\
Range & $81-271$ \\
Cd34, Average \pm Sd & $98 \pm 56$ \\
Range & $21-192$ \\
Condicioning Regimen & \\
Flu - Cy, n (\%) & $5(42)$ \\
Arc- Flu, n (\%) & $2(16)$ \\
Bu - Flu-Cy, n (\%) & $5(42)$ \\
& \\
\hline
\end{tabular}

\begin{tabular}{|c|c|}
\hline Characteristics & Total $(n=12)$ \\
\hline Age in years, Median (RIC) & $7.9(3.3-13.4)$ \\
\hline Male, n (\%) & $6(50)$ \\
\hline \multicolumn{2}{|l|}{ Weight in kg } \\
\hline Average $\pm \mathrm{Sd}$ & $27 \pm 16$ \\
\hline Range & $6.9-59.5$ \\
\hline \multicolumn{2}{|l|}{ Diagnosis } \\
\hline Fanconi anemia, n (\%) & $2(17)$ \\
\hline Sickle cell disease, n (\%) & $4(33)$ \\
\hline Immunodeficiency, n (\%) & $6(50)$ \\
\hline \multicolumn{2}{|l|}{ Source Cells } \\
\hline Bone marrow, n (\%) & $6(50)$ \\
\hline Peripheral blood, n (\%) & $4(33)$ \\
\hline $\begin{array}{l}\text { Bone marrow + Peripherally } \\
\text { Blood, n (\%) }\end{array}$ & $2(17)$ \\
\hline Follow up time in days, Median (RIC) & $28.6(19.5-42.4)$ \\
\hline
\end{tabular}

\section{TLI Radiotherapy}

The time of treatment with TLI in the majority of patients (seven patients) was more than $90 \mathrm{~min}$. The number of irradiated fields was between 20 and 40 . The dose of radiotherapy received corresponded to a median of $750 \mathrm{cGy}$ (IQR: 400-750). Overall, $83.3 \%$ of patients received TLI on day -1 , and the remaining patients were treated on day -8 (Table 3).

\section{Hematopoietic Cell Transplantation}

The most commonly used source of cells was bone marrow in $6 / 12$ patients, followed by peripheral blood in 4/12 patients, and both in two patients according to the medical decision. The average number of nucleated cells was $153 \pm 58$ per 107 , with a range of $81-271$, and the average number of CD34+ cell was $98 \pm 56$ per $105 / \mathrm{kg}$, with a range of 21 - 192. On average, all patients had a neutrophil graft at $16 \pm 3$ days. One patient had failure of primary platelet grafting, and the average platelet graft in 11/12 patients was 15 days (IQR: 14-18). Three patients with hemoglobinopathies had graft failure followed by autologous recovery. 


\begin{tabular}{|c|c|}
\hline & Total $(n=12)$ \\
\hline Acute Gvhd Per Grade, n (\%) & 7 (58) \\
\hline Grade I, n & 7 \\
\hline Grade II, n & 4 \\
\hline Grade III, n & 2 \\
\hline Grade IV, n & 0 \\
\hline \multicolumn{2}{|l|}{ Acute GVHD per organs affected } \\
\hline Gastrointestinal, n (\%) & $5(71.5)$ \\
\hline Skin, n (\%) & $3(43)$ \\
\hline Liver, n (\%) & $2(28.5)$ \\
\hline Chronic GVHD, n (\%) & $5(55)$ \\
\hline Severe, n (\%) & $1(11)$ \\
\hline
\end{tabular}

\section{Posttransplant Complications}

Approximately 58\% presented acute GVHD, mostly Grade II (57\%), followed by grade III (28\%). The system with the greatest compromise was the gastrointestinal system (71\%). Chronic GVHD was documented in 5/12 patients; of these, one was diagnosed with severe chronic GVHD (Table 4).

The main cause of infection was bacteria in half of the cases, followed by viral and fungal infections. In this last group, there were three cases of Aspergillus. Mucositis occurred in less than half of patients (5/12) (Table 5).

The two-year nonrelapse mortality was $17 \%$ and was due to infectious cause, which occurred in the first 100 days after transplantation, one for fungal infection and one viral infection (Table 5).

\section{Peripheral Blood Chimerism}

On day $180,5 / 12$ patients reached $100 \%$ chimerism of the donor cells, $1 / 12$ reached $80 \%, 1 / 12$ reached $60 \%, 1 / 12$ reached $20 \%$, and $2 / 12$ reached $0 \%$; two patients died before 180 days (Table 5).

\section{Survival}

The OS was $83 \%$ at one year and at five years. The event-free survival was $58 \%$ at both one year and five years (Figures 1 and 2).

\begin{tabular}{|c|c|}
\hline Outcomes & Total $(n=12)$ \\
\hline \multicolumn{2}{|l|}{ Infections } \\
\hline Bacterial n (\%) & $6(50)$ \\
\hline Viral n (\%) & $4(34)$ \\
\hline Fungal n (\%) & $3(25)$ \\
\hline Mucositis, n (\%) & $5(42)$ \\
\hline $100 \%$ donor chimerism at day $180, \mathrm{n}(\%)$ & $5(42)$ \\
\hline \multicolumn{2}{|l|}{ Days until donor chimerism $100 \%$} \\
\hline Average $\pm \mathrm{Sd}$ & $106 \pm 53$ \\
\hline Range & $30-180$ \\
\hline Time of neutrophil engraftment, Median (RIC) & $16(15-18)$ \\
\hline Time of platelet engraftment, Median (RIC) & $15(14-18)$ \\
\hline Primary graft failure, $\mathrm{n}(\%)$ & $1(8)$ \\
\hline Autologous recovery, n (\%) & $3(25)$ \\
\hline Mortality, n (\%) & $2(17)$ \\
\hline Fungal Infection, n & 1 \\
\hline Viral Infection, $\mathrm{n}$ & 1 \\
\hline
\end{tabular}

\section{DISCUSSION}

This case series summarizes the experience of pediatric patients diagnosed with benign pathologies who were treated with allogenic HSCT using a TLI/ATG conditioning regime and post-HSCT $\mathrm{Cy}$ with haploidentical donors at a tertiary care institution from 2015 - 2017. The results presented show a favorable outlook with the use of this combination, offering the possibility of irradiating fewer body areas. However, the GVHD decrease was not expected. To our knowledge, there are few publications with the characteristics of this study, especially regarding the use of posttransplant $\mathrm{Cy}$; therefore, it is necessary to continue studying this population.

The most common benign pathologies reported in this study were immunodeficiencies, sickle cell anemia, and Fanconi anemia, similar to other reports in the literature. ${ }^{21,22}$ Characteristically, we described three cases with graft failure, all related to patients with sickle cell anemia. We considered this to be associated with the high rates of failure in these pathologies. ${ }^{23}$

The literature has described the use of TLI and ATG as conditioning prior to the first and/or sec- 


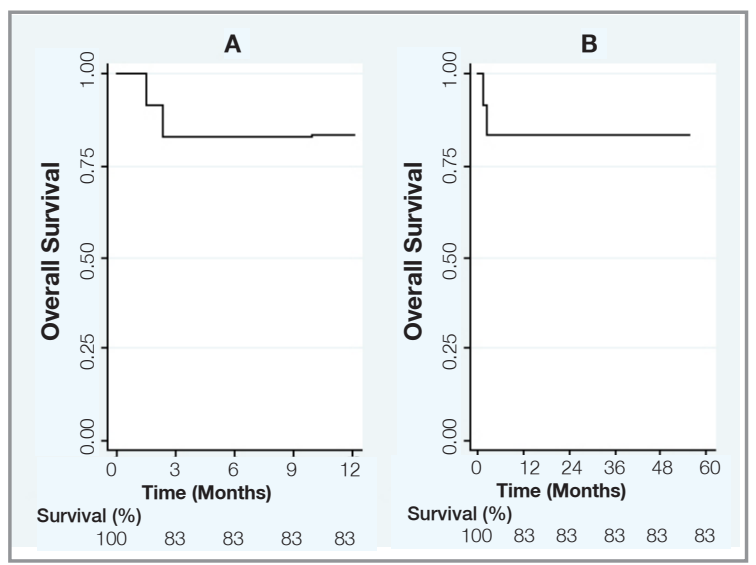

Figure 1. Overall survival in post-Hematopoietic stem cell transplantation patients during the first twelve months $(\mathbf{A})$ and by year until fifth-year (B).

ond HSCT (24) in pediatric and adult populations with malignant and nonmalignant diseases with good results. ${ }^{6,21,22,25-34}$ TLI has also been used in HSCT with different types of donors, as HLAidentical related and nonrelated donors for benign diseases. ${ }^{6,12,21,25,28,29,32-34}$ In the case of haploidentical donors, the published literature refers mainly to protocols involving graft manipulation ${ }^{13}$, but in our study, we used unmanipulated replete $\mathrm{T}$ cells.

This study showed an incidence of $58 \%$ and $42 \%$ of acute and chronic GVHD, respectively, which is similar to another study in our institution of patients with malignant pathologies treated with haploidentical HSCT with post-HSCT Cy and different conditioning regimens, in whom the incidence of acute GVHD was $59 \% .^{35}$ This similarity is probably due to the low dose of ATG used. Other studies performed in pediatric patients with benign pathologies have shown a lower incidence of Grade II-IV acute GVHD between 0 and 17\%. ${ }^{28,36,37}$ However, these studies included patients with identical family donors, which was not our case. Experimental studies and reports in humans may suggest that post-HSCT Cy and the use of TLI have been associated with a lower risk of acute GVHD. ${ }^{38}$ To our knowledge, there are no cases published regarding the combination of TLI with post-HSCT Cy in haploidentical HSCT.

The one- and five-year OS in this study was $85 \%$, according to the range of values reported in other centers $(83 \%-100 \%)^{28,36}$ and the one- and fiveyear event-free survival was $61 \%$, close to that re-

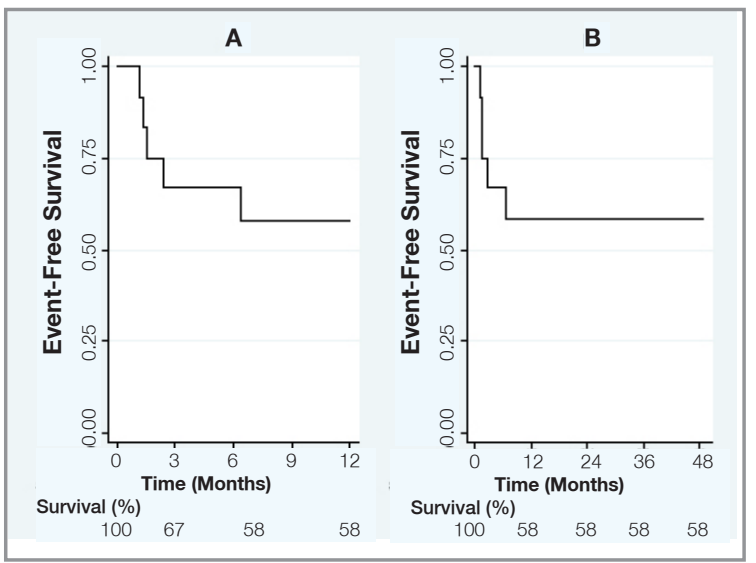

Figure 2. Event-free survival in post-Hematopoietic stem cell transplantation patients during the first twelve months $(\mathbf{A})$ and by year until fourth-year (B).

ported in the literature $(67 \%$ and $100 \%))^{6,22,29,32-34}$ However, the comparable studies do not meet the same characteristics of our study due to the scarce information. The treatment-related mortality and GVHD in our patient were not decreased as expected. To the best of our knowledge, this is the largest series of patients with these characteristics. This study has some limitations. The collection of retrospective data was limited to the information recorded in the medical records. Adverse events with TLI were not sought. The opportunity for HSCT in benign pathologies should continue to be studied. This study has a favorable impact and encourages researchers and practicing physicians to explore alternatives in the peri-transplant period to decrease the symptoms of underlying disease and posttransplant complications.

\section{Conclusion}

Pre-HSCT conditioning with TLI/ATG and the use of post-HSCT Cy in haploidentical HSCT is a novel approach to transplantation in benign disorders in children and should be explored in prospective studies. Further studies and long-term follow-up are required to evaluate this therapeutic option.

\section{REFERENCES:}

1. Mochizuki K, Kikuta A, Ito M, et al. Feasibility of tacrolimus, methotrexate, and prednisolone as a graft-versus-host disease prophylaxis in non-T-cell-depleted haploidentical hematopoietic stem cell transplantation for children. Clin Transplant 25: 892-897, 2011. 
2. Duarte RF, Labopin M, Bader P, et al. Indications for haematopoietic stem cell transplantation for haematological diseases, solid tumours and immune disorders: current practice in Europe, 2019. Bone Marrow Transplant 54: 1525-1552, 2019.

3. Majhail NS, Farnia SH, Carpenter PA, et al. Indications for autologous and allogeneic hematopoietic cell transplantation: Guidelines from the American Society for Blood and Marrow Transplantation. Biol Blood Marrow Transplant 21: 18631869, 2015

4. Hladun R, Badell I, González M, et al. Análisis de la supervivencia de los niños con inmunodeficiencias primarias que han recibido un trasplante de progenitores hematopoyéticos en España. An Pediatría 82: 62-67, 2015.

5. Grunebaum E, Roifman CM. Bone marrow transplantation using HLA-matched unrelated donors for patients suffering from severe combined immunodeficiency. Hematol Oncol Clin North Am 25: 63-73, 2011.

6. Lee YH, Kim JY, Choi BO, et al. Total lymphoid irradiation based conditioning for hematopoietic stem cell transplantation in severe aplastic anemia. Radiat Oncol J 30: 165-172, 2012.

7. Ramsay N, Kim T, Nesbit M, et al. Total lymphoid irradiation and cyclophosphamide as preparation for bone marrow transplantation in severe aplastic anemia. Blood 55: 344-346, 1980.

8. Hussein AA, Al-Zaben A, Ghatasheh L, et al. Risk adopted allogeneic hematopoietic stem cell transplantation using a reduced intensity regimen for children with thalassemia major. Pediatr Blood Cancer 60: 1345-1349, 2013.

9. Ballen KK, Koreth J, Chen YB, et al. Selection of optimal alternative graft source: Mismatched unrelated donor, umbilical cord blood, or haploidentical transplant. Blood 119: 19721980, 2012.

10. Kohrt H, Lowsky R. Total lymphoid irradiation for graft-versus-host disease protection. Curr Opin Oncol 21 (Suppl 1): S23-26, 2009.

11. Kohrt H, Lowsky R. Nonmyeloablative conditioning with total lymphoid irradiation and antithymocyte globulin: An update. Vol. 16, Current Opinion in Hematology 16: 460-465, 2009.

12. Ocanto A, Escribano A, Glaría L, et al. TLI in pediatric patients. Clin Transl Oncol 22: 884-891, 2020.

13. Balashov D, Shcherbina A, Maschan M, et al. Single-center experience of unrelated and haploidentical stem cell transplantation with TCR $\alpha \beta$ and CD19 depletion in children with primary immunodeficiency syndromes. Biol Blood Marrow Transplant 21: 1955-1962, 2015.

14. Jacoby E, Chen A, Loeb DM, et al. Single-agent post-transplantation cyclophosphamide as graft-versus-host disease prophylaxis after human leukocyte antigen-matched related bone marrow transplantation for pediatric and young adult patients with hematologic malignancies. Biol Blood Marrow Transplant 22: 112-118, 2016.
15. Munchel A, Kesserwan C, Symons HJ, et al. Nonmyeloablative, HLA-haploidentical bone marrow transplantation with high dose, post-transplantation cyclophosphamide. Pediatr Rep 3(2S): 43-47, 2011.

16. Lopez-Hernandez G, Lopez-Santiago N, Olaya-Vargas A, et al. Haploidentical stem cell transplantation with posttransplant cyclophosphamide as graft-versus-host disease prophylaxis in pediatric hematologic malignancies. Blood 132 (Supplement 1): 5705-5705, 2018.

17. Lum SH, Hoenig M, Gennery AR, Slatter MA. Conditioning regimens for hematopoietic cell transplantation in primary immunodeficiency. Curr Allergy Asthma Rep 19: 52, 2019.

18. Al-Homsi AS, Roy TS, Cole K, et al. Post-transplant highdose cyclophosphamide for the prevention of graft-versushost disease. Biol Blood Marrow Transplant 21: 604-611, 2015.

19. Medina D, Estacio M, Rosales M, Manzi E. Haploidentical stem cell transplant with post-transplantation cyclophosphamide and mini-dose methotrexate in children. Hematol Oncol Stem Cell Ther 1-6, 2020 (On-line).

20. Tomblyn M, Chiller T, Einsele H, et al. Guidelines for preventing infectious complications among hematopoietic cell transplantation recipients: A global perspective. Biol Blood Marrow Transplant 15: 1143-238, 2009.

21. Matthes-Martin S, Lawitschka A, Fritsch G, et al. Stem cell transplantation after reduced-intensity conditioning for sickle cell disease. Eur J Haematol 90: 308-312, 2013.

22. Vermylen C, Cornu G, Ferster A, et al. Haematopoietic stem cell transplantation for sickle cell anaemia: the first 50 patients transplanted in Belgium. Bone Marrow Transplantat 22: 1-6, 1998.

23. Abraham A, Hsieh M, Eapen M, et al. Relationship between mixed donor-recipient chimerism and disease recurrence after hematopoietic cell transplantation for sickle cell disease. Biol Blood Marrow Transplant 23: 2178-2183, 2017.

24. Tumino M, Mainardi C, Pillon M, et al. Haploidentical TCR A/B and B-cell depleted hematopoietic SCT in pediatric SAA and aspergillosis. Bone Marrow Transplant 49: 847-849, 2014.

25. Heinzelmann F, Lang PJ, Ottinger $\mathrm{H}$, et al. Immunosuppressive total lymphoid irradiation-based reconditioning regimens enable engraftment after graft rejection or graft failure in patients treated with allogeneic hematopoietic stem cell transplantation. Int J Radiat Oncol Biol Phys 70: 523-528, 2008.

26. Kohrt HE, Turnbull BB, Heydari K, et al. TLI and ATG conditioning with low risk of graft-versus-host disease retains antitumor reactions after allogeneic hematopoietic cell transplantation from related and unrelated donors. Blood 114: 1099-1109, 2009.

27. Spinner MA, Kennedy VE, Tamaresis JS, et al. Nonmyeloablative TLI-ATG conditioning for allogeneic transplantation: Mature follow-up from a large single-center cohort. Blood Adv 3: 2454-2464, 2019. 
28. Steiner M, Matthes-Martin S, Attarbaschi A, et al. Improved outcome of treatment-resistant high-risk Langerhans cell histiocytosis after allogeneic stem cell transplantation with reduced-intensity conditioning. Bone Marrow Transplant 36: 215-225, 2005

29. Pillai A, Hartford C, Wang C, et al. Favorable preliminary results using TLI/ATG-based immunomodulatory conditioning for matched unrelated donor allogeneic hematopoietic stem cell transplantation in pediatric severe aplastic anemia. Pediatr Transplant 15: 628-634, 2011.

30. Lowsky R, Takahashi T, Liu YP, et al. Protective Conditioning for Acute Graft-versus-Host Disease. N Engl J Med 353: 1321-1331, 2005.

31. Messina G, Giaccone L, Festuccia M, et al. Multicenter Experience using total lymphoid irradiation and antithymocyte globulin as conditioning for allografting in hematological malignancies. Biol Blood Marrow Transplant 18: 1600-1607, 2012.

32. Tan PL, Wagner JE, Auerbach AD, et al. Successful engraftment without radiation after fludarabine-based regimen in fanconi anemia patients undergoing genotypically identical donor hematopoietic cell transplantation. Pediatr Blood Cancer 46: 630-636, 2006.

33. Kobayashi R, Yabe H, Hara J, et al. Preceding immunosuppressive therapy with antithymocyte globulin and ciclosporin increases the incidence of graft rejection in children with aplastic anaemia who underwent allogeneic bone marrow transplantation from HLA-identical siblings. $\mathrm{Br} \mathrm{J}$ Haematol 135: 693-696, 2006.

34. Hussein A, Al-Mousa A, Khattab E, et al. TLI-based reducedintensity conditioning hematopoietic SCT for children and adolescents with high-risk nonmalignant disorders. Bone Marrow Transplant 50: 452-454, 2015.

35. Medina D, Gonzales L, Davalos D, et al. Trasplante de células madre hematopoyéticas en pacientes pediátricos con diagnóstico de neoplasias mieloides, experiencia en 15 años. Rev Colomb Cancerol 22: 69-75, 2018.
36. Krishnamurti L, Kharbanda S, Biernacki MA, et al. Stable long-term donor engraftment following reduced-intensity hematopoietic cell transplantation for sickle cell disease. Biol Blood Marrow Transplant 14: 1270-1278, 2008.

37. Gaziev D, Giardini C, Galimberti M, et al. Bone marrow transplantation for transfused patients with severe aplastic anemia using cyclophosphamide and total lymphoid irradiation as conditioning therapy: long-term follow-up from a single center. Bone Marrow Transplant 24: 253-257, 1999.

38. Devillier R, Castagna L, Gonzague $L$, et al. TLI in refractory chronic GVHD. Bone Marrow Transplant 48: 854-858, 2013.

\section{Correspondence:}

Dr. Diego Medina VALENCIA

Fundación Valle del Lili

Pediatric Stem Cell Transplantation Service

Carrera 98 No: 18-49

Cali 760032, COLOMBIA

Tel: 5723319090 ext 8801

e-mail: diego.medina@fvl.org.co

\section{ORCIDs:}

Catalina María Acevedo-Henao

0000-0002-9559-0116 Nelson Romero-Rosas Estefania Beltran

Eliana Manzi

0000-0001-8406-6848 0000-0003-2438-8356 $0000-0001-5577-970 X$

Alexis Antonio Franco Moreno $0000-0002-3173-6059$ Mayra Estacio

Guillermo Potdevin Stein 0000-0001-6908-2508 0000-0002-9876-4222

Diego Medina Valencia 